\title{
Relationship between Participation and Social Inclusion
}

\author{
Louis Nwachi \\ Technological University, Dublin, Ireland \\ Email: louis.nwachi@tudublin.ie
}

How to cite this paper: Nwachi, L. (2021). Relationship between Participation and Social Inclusion. Open Journal of Social Sciences, 9, 46-77.

https://doi.org/10.4236/jss.2021.910004

Received: September 2, 2021

Accepted: October 10, 2021

Published: October 13, 2021

Copyright $\odot 2021$ by author(s) and Scientific Research Publishing Inc. This work is licensed under the Creative Commons Attribution International License (CC BY 4.0).

http://creativecommons.org/licenses/by/4.0/

\begin{abstract}
Studies show that within most countries, there are generally many different socio-cultural, ethnic and religious groups and this diversity inevitably creates a level of inter-group tension, with income disparities, cultural differences, and intergroup segregation leading in turn to social exclusion. This paper set out to develop a conceptual framework to examine the relationship between that participation and the social inclusion outcomes in the plan-making process. It addressed how social inclusion can relate to the plan-making process culturally, politically and institutionally, economically and socially with high level participation. In doing this, it adopted a case study approach using the Metropolitan Area of Abuja, the capital of Nigeria as the study sample of multi-ethnic, cultural and religious area. The research finds that participation in the plan-making process has a direct impact on social inclusion outcomes, helping to: break down cultural barriers; create intergroup cohesion; alleviate poverty; increase economic opportunities; and promote good governance. It finds that the relationship between participation and social inclusion varies across different indicators of social inclusion. It shows a very strong or moderately strong relationship across different indicators. However, the significance of relationship is very strong across all the indicators.
\end{abstract}

\section{Keywords}

Plan-Making, Social Inclusion, Participation

\section{Introduction}

Participation in urban planning is an approach that involves people and the development of their communities (Fiskaa, 2007). It is where the beneficiary communities participate in a particular way on the implicit assumption that 
their participation is a means to some further action on their part to bring about specific change (UN-Habitat, 2009). The act of invitation to engage in the decision-making process is seen by the public as a sign of acceptance by the government of public input (Marzuki, 2015). The UDP (2013) notes that the public is usually affected by urban planning projects, and it is essential that they participate in the decision making process from the stage, as this will encourage them to input into the plan-making process and to present the views of the entire community on specific issues to ensure the development of socially inclusive projects. This is to say that public participation is key to social inclusion in planning and development (Marzuki, 2015).

Much has been written about the lack of empirical studies and literature more generally in the area of social inclusion in the plan-making process (Forester, 1999; Fainstein, 2010; Brenman \& Sanchez, 2012). Furthermore, numerous studies by scholars and practitioners such as Jiriko (2008), Mabogunje (2001, 2002), and Oyesiku (2004) have shown that most plan-making approaches in cities in developing countries have failed to address the problem of urban development and management of urban areas due to lack of social inclusion processes and practices in the urban planning system. Also, since the mid-19th century, urban historians, planners, and theorists such as Jon Forester, Marc Brennan, Tom Sanchez, and Susan Fainstein have argued that urban planning is not democratic enough and often fails to achieve social inclusion (Forester, 1999; Fainstein, 2010; Brenman \& Sanchez, 2012). In the context of these observations, this study, and its conclusions and broader application, are particularly timely in understanding the relationship between participation and social inclusion in the plan-making process.

\section{Literature Review}

\section{Relationship between Participation and Social Inclusion}

Social inclusion is a process of improving the participation of citizens, especially those that are disadvantaged in society, through enhancing opportunities, access to resources, voice and respect for rights (UNRISD, 2015). Promoting social inclusion requires tackling social exclusion by removing barriers to people's participation in the society, as well as by taking active inclusionary steps to facilitate such participation (UNRISD, 2015). Participation can be a deliverable of social inclusion and can also be seen as a tool to achieve social inclusion, as shown in Figure 1 and Figure 2 (UN-Habitat, 2013b). The relationship between participation and social inclusion can be seen as a process which ensures that those at risk of poverty and social exclusion gain the opportunities and resources necessary to participate fully in economic, social and cultural life, and to enjoy a standard of living and well-being that is considered normal in the society in which they live (Cambir \& Vasile, 2015). It ensures that the citizens have greater participation in the decision-making process which affects their daily lives and access to fundamental rights (UNDESA, 2014). 


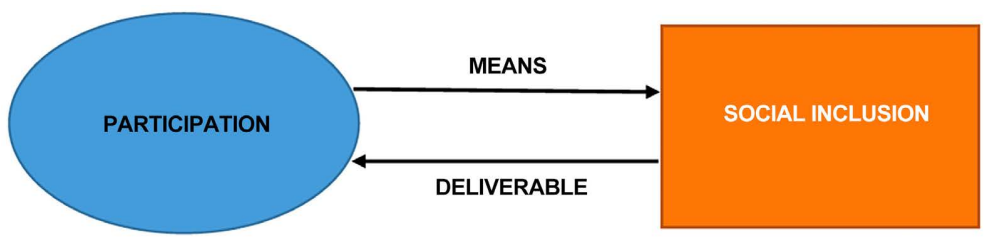

Figure 1. Relationship diagram between participation and social inclusion (Source: Author based on UN-Habitat, 2013b).

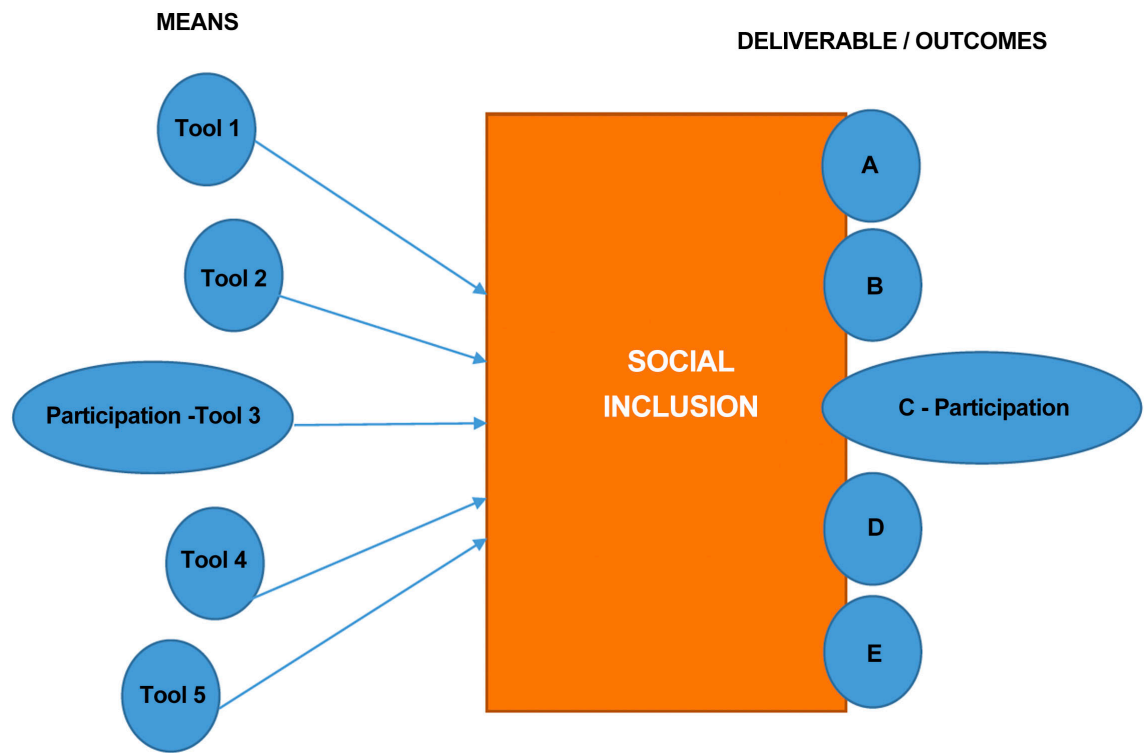

Figure 2. Relationship diagram between participation and social inclusion outcomes (Source: Author based on UN-Habitat, 2013b).

Social inclusion can be seen as both a process and an outcome (UN-Habitat, 2013b). This definition merges the desired outcome, "well-being that is considered normal" with the process through which it can be achieved, "opportunities for participation" (see Figure 2).

Kirby et al. (2003) highlight that participation can help establish a social inclusive practice that helps fulfil an obligation to ensure basic rights. They also argue that it helps to empower the less privileged in the society to effect change and to develop the self-belief in their ability to influence outcomes. It can also offer people opportunities to have increased responsibility within their lives, improve community relationships and enhance community feeling (Kirby et al., 2003). Kalenzig (2011) explains that urban planning policies and practices are always likely to impact strongly on social issues, so tools and approaches for promoting social inclusion are very important. Therefore, the promotion of public participation in decision-making is important in achieving social inclusion. Kalenzig also observes that tools for plan-making can stimulate social and organisational learning and provide a process for enhancing stakeholders' understanding of how to prepare for and manage change, risk and uncertainty. Engaging the grassroots in the plan-making process helps put new urban solutions into practice (Kalenzig, 2011). 
The UNRISD (2015) highlights that participation encompasses involvement in various social, cultural, economic or political aspects of life. This can be achieved by strengthening the public's capacity to influence decision-making processes and exercise their claims on external actors and institutions that affect their lives. Social inclusion is strengthened through participation in the plan-making process, which will lead to more social capital and enhanced local ownership. The United Nations notes that local ownership is a growth process that imposes demands on both the public and the municipality. Differences of opinion about a plan normally stimulate both sides to think about how participation and responsibility can be shared (Cilliers et al., 2011; UNRISD, 2015). Achieving the objective of the plan is expressed through openness and equal contributions among the different stakeholders on reaching a shared vision in the plan-making process (Cilliers et al., 2011). Studies show that such an approach has a positive impact on the plan-making process, because communities feel more engaged and are more willing to cooperate in future planning and developments (Cilliers et al., 2011; UNRISD, 2015). The potential for an urban planning system to implement an inclusive approach depends on its geography, demographics trends, economic structures, cultural aspects and administrative context (WHO, 1999; Andrew, 2015). Social inclusion can be categorised under three different headings: socio-cultural, political and economic (Andrew, 2015; UN, 2010). Studies show that these different categories of social inclusion have a unique relationship with participation (Imatunga, 2006; Slack \& Cote, 2014; Schoukens et al., 2015).

\subsection{Relationship between Participation and the Socio-Cultural Aspects of Social Inclusion}

Studies show that empowering different socio-cultural groups in the society through participation in the plan-making process will help create a sense of inclusion in such a group (UN-Habitat, 2016). Urban institutions must have sufficient capacity to facilitate agreement among residents on the path forward, build social trust, provide security and enhance access to basic services (UN-Habitat, 2013a). This process should ensure access to good quality information and equal opportunities for participation. Long-term and large-scale impacts and the interests of future generations need to be considered in urban planning and decision-making processes (GAC, 2011). Most urban planning systems face the challenge of making it possible for stakeholder groups with structurally weak representation to take part in the plan-making process while safeguarding their interests and without fostering a nonchalant attitude (GAC, 2011).

Imatunga (2006) highlights that the participation of indigenous or different socio-cultural groups in the decision-making process can be seen as the basis for a more socially inclusive urban planning practice. Thus, ensuring that the more marginalised and disempowered communities in the society are included in the planning process is essential (Imatunga, 2006). He suggests that the inclusion of 
these groups in the plan-making process needs to proceed by first accepting that all countries with indigenous peoples have an indigenous planning tradition and practice. Also, indigenous planning should be part of the urban planning system which will eventually provide the basis for participation of the indigenous people in the plan-making process (Imatunga, 2006).

\subsection{Relationship between Participation and the Political/Institutional Aspects of Social Inclusion}

The UN-Habitat notes that due to insufficient public participation in developing countries, many urban areas in these regions suffer institutional and political power influence from public institutions and leaders, by allowing them to take outright authority to influence decisions and human behaviour (UN-Habitat, 2016b). Here collective decision-making has failed to address the gap between national developmental agendas and local needs (Jones et al., 2014). These processes have excluded women, youth, minorities, the urban poor and those with disabilities from the decision-making (UN-Habitat, 2016b). Jones et al. (2014) argue that more attention needs to be paid to the political drivers that enhance inclusive policy, goods, and services. It is important to understand both the political economy that underlies institutions of urban governance and how local power hierarchies influence the distribution and allocation of resources (Shah \& Shah, 2006). With a wide range of actors (formal and informal) participating at different levels in decision-making, there is a need to foster a network-based planning process, instead of a hierarchical governance structure (Jones, 2008). Limited capacity, performance, and legitimacy of different levels of government, and the immaturity of political institutions can undermine urban governance and result in corrupt practices (Slack \& Cote, 2014).

Social inclusion helps strengthen the technical and institutional capacities of cities to manage urbanization by integrating all stakeholders in the urban planning, design, legislation, and governance of the urban environment (UN-Habitat, 2016b). Access and influence in decision-making in the plan-making and governance process is an important form of participation that is relevant for inclusive planning (Dugarova \& Lavers, 2014). The World Social Forum has called for a more direct, democratic public involvement in decision-making at the local and national government levels to bridge the social and institutional gap that exists (Silver, 2015). It is now seen by a wide range of scholars and institutions as an empowering, inclusionary, and democratic means to progressive, redistributive ends (Godfrank \& Schrank, 2009; Silver, 2015). Public participation aims to deepen democracy, increase transparency, and promote greater efficiency, thereby increasing public trust in government (Godfrank \& Schrank, 2009). This helps to empower ordinary residents, build community, give voice to the voiceless and promote integration in the society (Fung \& Wright, 2001). Silver (2015) argues that public participation, without public inclusion in the governance and decision-making process, will not benefit the marginalised.

Urban planners, or those in authority, need to identify diverse community in- 
terests and important stakeholders to be involved in the urban governance process in order to build partnerships and alliances (Mitlin \& Thompson, 1995). By encouraging the participation of these stakeholders and political actors, in the plan-making process, it helps identify major urban problems the community is facing, detect causes and consequences, embrace diverse solutions and construct suitable responses (Sotomayor-Morales et al., 2017).

\subsection{Relationship between Participation and the Economic Aspects of Social Inclusion}

The promotion of social inclusion has been integrated as a guideline into the broader economic and employment monitoring process of the EU social policy (Schoukens et al., 2015). This new approach has developed through an enhanced socio-economic policy coordination, with a view to achieving smart growth, sustainable growth and inclusive growth, which are expected to be mutually reinforcing (Schoukens et al., 2015). Inclusive growth entails fostering a high-employment economy and delivering social and territorial cohesion. It also empowers people through the provision of higher levels of employment, investing in skills, fighting poverty and modernising labour markets, training, and social protection systems. This approach will not only help foster social inclusion but also help people anticipate and manage change and build a cohesive society (Schoukens et al., 2015).

Dugarova and Lavers (2014) observe that one of the ways to achieve social inclusion is through economic stability, and that social inclusion is explicitly intertwined with employment and economic guidelines. The participation rate of a society is a social indicator, used to assess social inclusion in an urban planning system. Fernandez-Borrero and Vazquez-Aguado (2014) note that the social integration of the marginalised population is closely linked to their participation in the labour market. Therefore, it is important that they are not left behind economically.

\section{Methods}

\subsection{Methodological Framework Concept}

In evaluating the relationship between participation and social inclusion in the plan-making process, a methodological framework concept was developed based on the literature that show that public participation in the plan-making process can play an important role in achieving social inclusion outcomes. From the literature, the plan-making process can be seen as a sequence of research processes, which are constantly reiterated through a return loop like an evolving document (Hall \& Tewdwr-Jones, 2011). Social inclusion can relate to the plan-making process culturally, politically and institutionally, economically and socially (UN, 2010). However, participation in each of these processes relates to social inclusion differently and can only be determined by the element or indicator in which it is related (UN, 2010). 
Participation in the plan-making process could be at high-level or low-level (Kingston, 1998). This study looks at high-level participation which involves public participation in the decision-making process, public participation in accessing consequences and recommending solutions, and finally, public participation in defining interest, actors, and agenda was considered in the development of the conceptual framework. This will be accessed against the plan-making stage of the plan-making process to determine its relationship with the different aspects of social inclusion outcomes as shown in Figure 3.

\subsection{Sampling Strategy}

Probability sampling technique was used on the quantitative data in this study because the researcher had little or no control over the choice of who was presented for selection. A simple random sampling of 100 participants was drawn from the local urban planning authority in charge of the Abuja municipal (Abuja Municipal Area Council) and the state urban planning authority in charge of the Abuja Federal Capital Territory (Federal Capital Development Authority) from full staff complement of approximately 400 officials as shown in Figure 4 . The authorities were considered in order to present an overview of the urban and regional planning system in FCT, Abuja, Nigeria.

\subsection{Data Analysis Approach}

\section{Quantitative Analysis Approach}

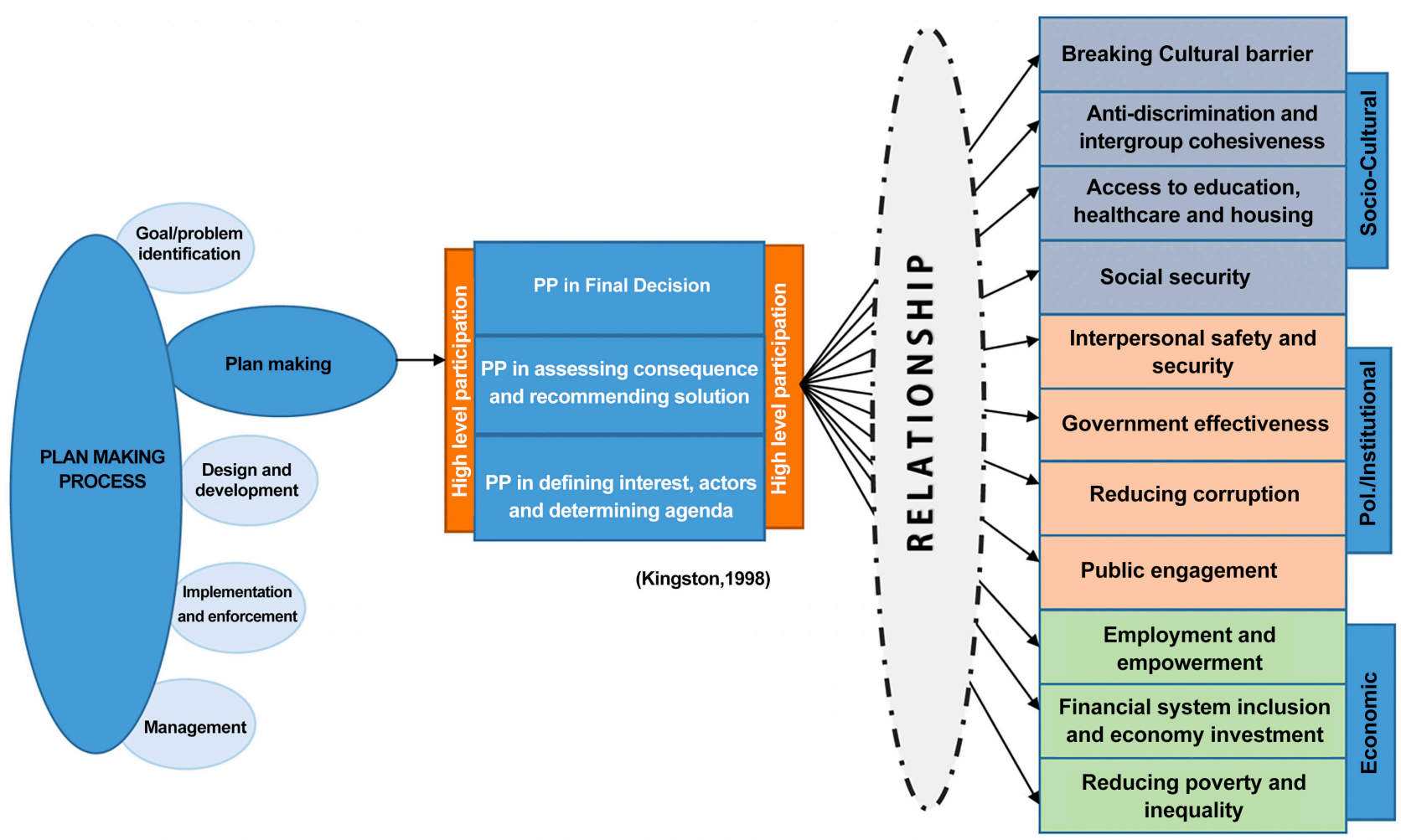

Figure 3. Relationship between participation and social inclusion methodological concept (Author). 


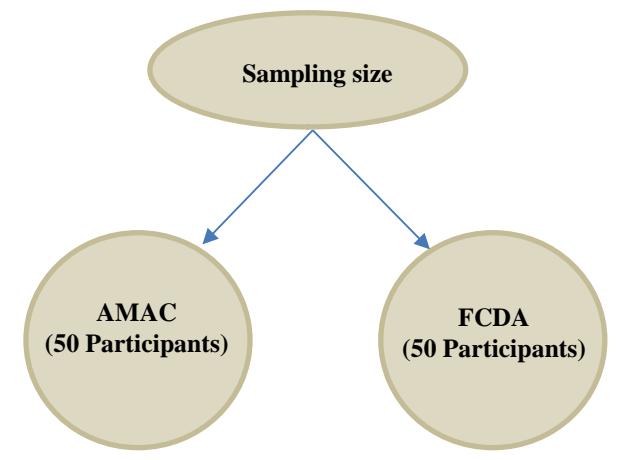

Figure 4. Diagram showing the probability sampling size for the research (Source: Author).

This study employed correlation to measure the relationship between the different social inclusion outcomes and participation in the plan-making process. It also evaluates the significance of these relationships. Pearson (1895) and Stigler (1989) describe correlation as a measure of the strength of the relationship between two variables. It is connected to the concept of statistical relationship between two variables. It quantifies the degree of change of one variable based on the change of the other variable (Stigler, 1989; Cohen, 1988). It has a value between +1 and -1 , where 1 is total positive linear correlation, 0 is no linear correlation, and -1 is total negative linear correlation as shown in Figure 5.

In scenarios where the correlation coefficient is positive, it shows that when a variable increases, the other variable has a tendency to also increase. While in situations where the correlation coefficient is negative, it indicates that when a variable increases, the other variable has a tendency to decrease. However, in a case where there is no correlation, it shows that the other variable does not tend to either increase or decrease (Cohen, 1988). Cohen (1988) highlights that when testing for the relationship between two variables it is important to note:

- Strength of relationship (availability of relationship)

- Level of significance of relationship

This research will not only evaluate the strength of the relationship between participation in the plan-making process and social inclusion outcomes, but it will also identify the level of significance of the relationship between the various variables.

\section{Strength of relationship (Availability of relationship)}

The correlation coefficient, $r$, tells us about the strength and direction of the linear relationship between different variables (Cohen, 1988). Shortell (2001) notes that there is no rule for determining what size of correlation is considered strong, moderate or weak. The interpretation of the coefficient depends on the topic of study. When studying things that are difficult to measure the correlation coefficients are lower, while when studying things that are easily countable the correlation coefficients are higher (Shortell, 2001). See Table 1.

This research aims to investigate how different social inclusion outcomes can be achieved through participation in the plan-making process. UNRISD (2015) 


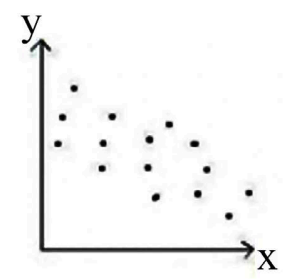

Negative correlation

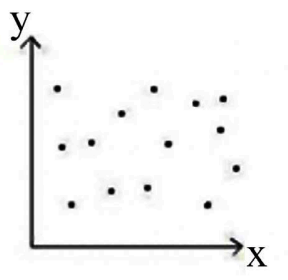

No correlation

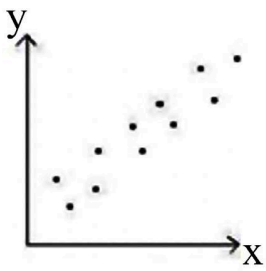

Positive correlation

Figure 5. Diagram showing range of correlation values (Source: Cohen, 1988).

Table 1. Table showing the strength of relationship for difficult and easy to measure variables (Source: Shortell, 2001).

\begin{tabular}{cccc}
\hline & Weak & Moderately strong & Relatively strong \\
\hline $\begin{array}{c}\text { Pearson correlation } \\
\text { (Difficult to measure })\end{array}$ & Below .2 & $.2-.4$ & Above .4 \\
$\begin{array}{c}\text { Pearson correlation } \\
\text { (Easy to measure })\end{array}$ & Below .45 & $.45-.75$ & Above .75 \\
\hline
\end{tabular}

notes that social inclusion cannot be easily measured, but can be evaluated based on the different social inclusion outcomes of a particular area. Social inclusion outcomes are not countable which makes it difficult to measure. Therefore, in this study, the correlation coefficient range to measure the strength of relationship for social inclusion outcomes and participation will be lower.

\section{Level of Significance of Relationship}

This research will use the Table of Critical Values to test for significance, assuming a significance level of 5 percent, $\alpha=.05$. This is because, the Table of Critical Values shows whether the computed value of $r$ is significant at different levels of percent in relation to the population (Siegle, 2015). It finds the critical values using the degrees of freedom, $d f=n-2$, and highlights the positive and negative critical value. If $r$ is not between the positive and negative critical values, then the correlation coefficient is significant and can be used to make predictions. In a case where $r$ is between the positive and negative critical values, the correlation coefficient is insignificant and cannot be used to make predictions (Siegle, 2015).

\section{Results}

The questionnaires were administered directly to fifty respondents at the FCDA and a further fifty questionnaires were administered at the AMAC. Forty-eight responses were received within two weeks of administration at the FCDA, while forty two responses were received at the AMAC within the same timescale, as shown in Figure 6.

The data shows a high response rate of $90 \%$. This response rate could be attributed to the researcher's ease of access to the different urban planning authorities in the study area, or to the sampling strategy and data collection technique used in the research. 


\section{Quantitative Data Presentation for the Relationship between Participa-} tion and Social Inclusion.

Respondents were asked about their level of agreement on the assertion that effective participation in the plan-making process helps improve social inclusion outcomes. The survey analysis shows that the majority of the respondents (85\%) agree that effective participation in the plan-making process helps improve social inclusion outcomes as shown in Figure 7. This suggests that there is clear support and agreement on the direct and positive impact of participation on social inclusion in the plan-making process. Only $6.7 \%$ of the respondents feel indifferent or have no opinion on its value, and less than $8 \%$ believe that effective participation in the plan-making process does not help improve social inclusion outcomes.

Quantitative Data Presentation for the Relationship between Participation and the Various Aspects of Social Inclusion.

Relationship between participation and the socio-cultural aspect of social inclusion

The following social inclusion outcomes were grouped under the socio-cultural aspects of social inclusion and were used to evaluate the possible socio-cultural outcomes, associated with high-level participation in the plan-making process:

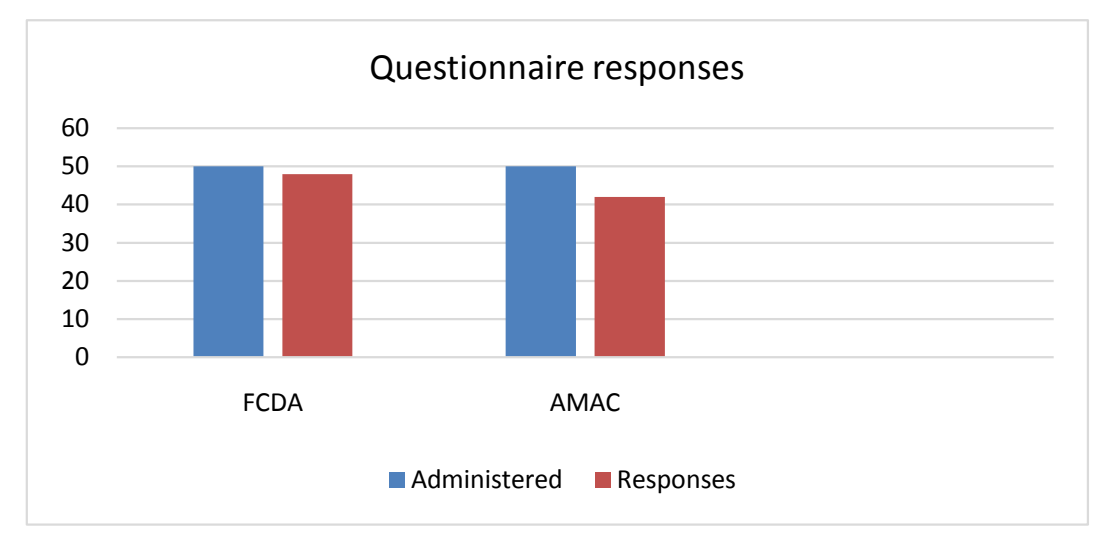

Figure 6. Chart showing questionnaire response rate from FCDA and AMAC (Source: Author).

Particpation helps improve Social Inclusion Outcomes

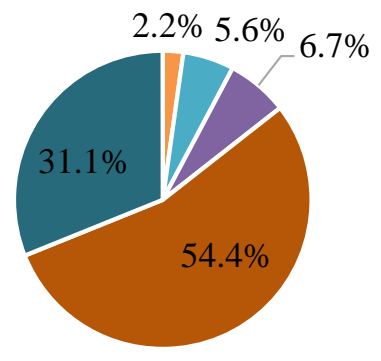

- Strongly disagree

- Disagree

- Indifferent

- Agree

- Strongly agree

Figure 7. Chart showing the level of agreement that effective participation in the plan-making helps improve social inclusion outcomes (Source: Author). 
- Breaking cultural barriers

- Anti-discrimination and intergroup cohesiveness

- Access to education, healthcare and housing

- Social security

From the survey data (Figure 8), the majority of the respondents (66.7\%) feel that with high-level public participation in the plan-making process, the possibility of breaking cultural barriers in the society will be high or very high. However, $13.4 \%$ of the respondents believe the possibility of breaking cultural barriers in the society will be low or non-existent when the public actively participate in the plan-making process. The correlative analysis in Table 2 shows a positive relationship between participation in the plan-making process and breaking cultural barriers in the society with a correlation of .401. The data indicate that the relationship between the two variables is relatively strong and significant.

Similar statistics relating to breaking cultural barriers in the society were recorded in relation to anti-discrimination and intergroup cohesiveness in the society. A total of $66.7 \%$ of the respondents suggest that when the public are part of the decision-making process, anti-discrimination and intergroup cohesiveness in the society will be high, while a mere $2 \%$ believe it will have no impact. As indicated in Table 2, the correlative relationship between participation and achieving anti-discrimination and intergroup cohesiveness in the society is positive, relatively strong and significant (.453).

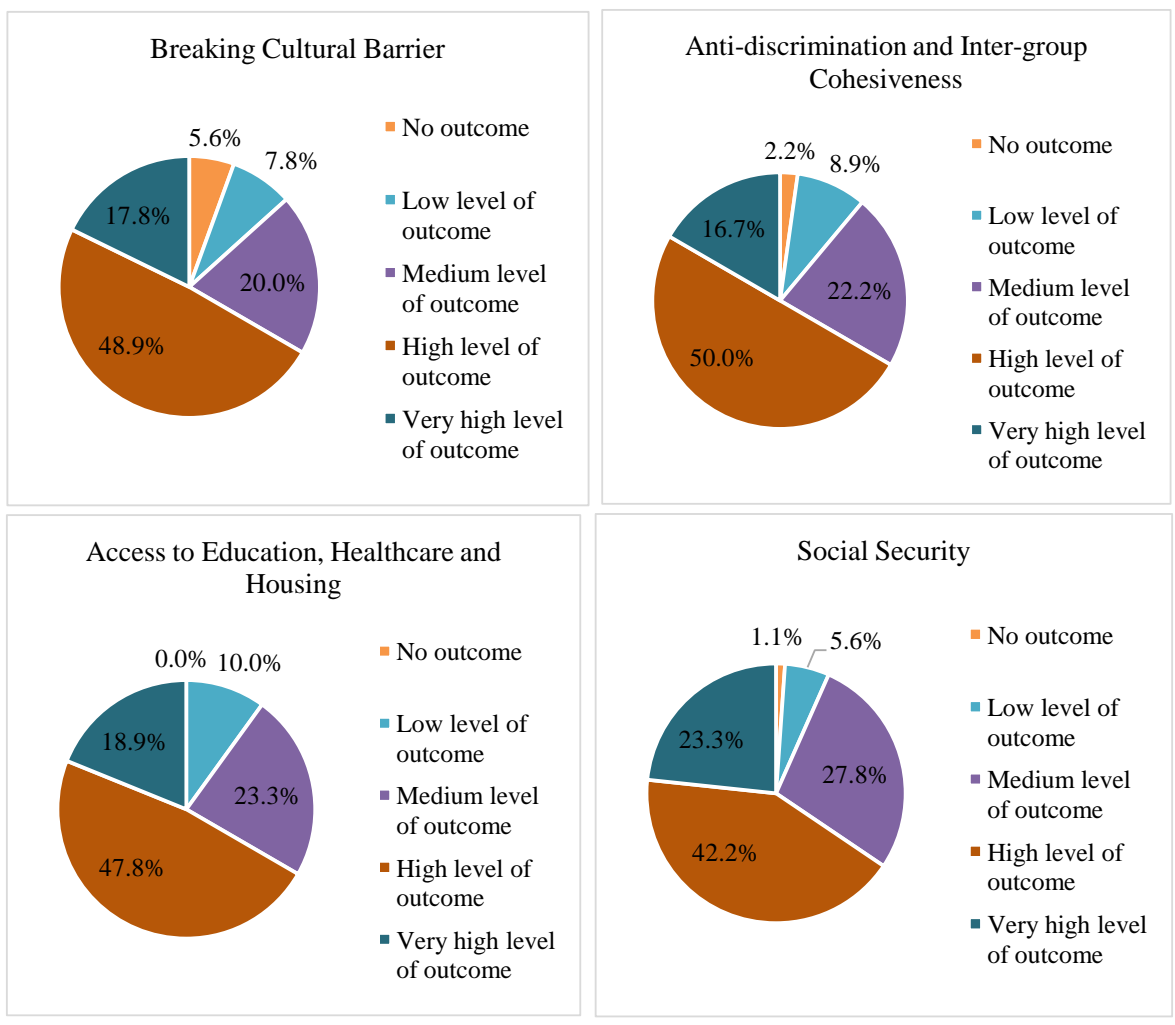

Figure 8. Chart showing the socio-cultural outcome in the urban planning system, associated with high-level participation in the plan-making process (Source: Author). 
In relation to access to education, healthcare, and housing, most of the respondents (67\%) believe that when the public are fully involved in the plan-making process, there is a high, or very high, possibility of their having access to these services. It can also be seen from the survey analysis in Figure 8, that no respondent feels that these services can be accessed without participation. Notwithstanding this, $10 \%$ of the respondents state that even with high-level participation in the plan-making process, they believe access to these services will be low. The correlative analysis indicates a positive relationship between participation in the plan-making process and the possibility of having access to education, healthcare, and housing in the society. With a correlation of .432, it means that the relationship is relatively strong and significant.

The survey data in Figure 8 also established that most of the respondents believe that social security for vulnerable groups in society can best be achieved when the public actively participate in the plan-making process. A total of $65.5 \%$ of the respondents score this social inclusion outcome as high or very high, when the plan-making process is publicly driven. $6.7 \%$ express the view that, even with high-level participation in the plan-making process, the possibility of achieving social security in the society will be low or non-existent. The data shows a correlation of .427 between participation in the plan-making process and achieving social security in the society (Table 2). This indicates that their relationship is positive, relatively strong and significant.

\section{Socio-cultural Indicators}

Table 2. Table showing the correlation between high-level participation in the plan-making process and socio-cultural indicators of social inclusion (Source: Author).

\begin{tabular}{|c|c|c|c|c|}
\hline & Breaking_Cultural_Barrier & $\begin{array}{c}\text { Anti_discrimination_Intergroup } \\
\text { Cohesiveness }\end{array}$ & Access_Education_Healthcare_Housing & Social_Security \\
\hline Valid & 90 & 90 & 90 & 90 \\
\hline Missing & 0 & 0 & 0 & 0 \\
\hline Mean & 3.66 & 3.70 & 3.76 & 3.81 \\
\hline Std. Deviation & 1.040 & .930 & .878 & .898 \\
\hline Variance & 1.082 & .864 & .771 & .807 \\
\hline Skewness & -.916 & -.735 & -.414 & -.471 \\
\hline Std. Error of Skewness & .254 & .254 & .254 & .254 \\
\hline
\end{tabular}

Importance_of_Participation_Plan_Making_Process

\begin{tabular}{ccc}
\hline & Pearson Correlation & $.401^{* *}$ \\
Breaking_Cultural_Barrier & Sig. (2-tailed) & .000 \\
& $\mathrm{~N}$ & 90 \\
\hline Anti_discrimination_Intergroup_Cohesiveness & Pearson Correlation & $.453^{* *}$ \\
\hline
\end{tabular}




\section{Continued}

\begin{tabular}{ccc}
\hline & Pearson Correlation & $.432^{* *}$ \\
Access_Education_Healthcare_Housing & Sig. (2-tailed) & .000 \\
& $\mathrm{~N}$ & 90 \\
\hline Social_Security & Pearson Correlation & $.427^{* *}$ \\
& Sig. (2-tailed) & .000 \\
\hline
\end{tabular}

${ }^{* *}$. Correlation is significant at the .01 level (2-tailed). ${ }^{*}$. Correlation is significant at the .05 level (2-tailed).

Relationship between participation and the political and institutional aspects of social inclusion

The following social inclusion outcomes were grouped under the political and institutional aspects of social inclusion and were used to evaluate the possible political and institutional outcomes associated with high-level participation in the plan-making process.

- Interpersonal safety and security

- Government effectiveness

- Reducing corruption

- Public engagement

From the survey data in Figure 9, the majority of the respondents (64\%) believe that interpersonal safety and security in the urban planning system will be high or very high, when the public is actively involved in the plan-making process. However, $35.5 \%$ of the respondents indicate their belief that high-level participation in the plan-making process does not guarantee a high level of interpersonal safety and security in the society. From the correlative analysis in Table 3 , it can be seen that the relationship between participation in the plan-making process and ensuring interpersonal safety and security in the society is moderately strong (.368). However it shows a positive and significant relationship between the two variables.

With regard to government effectiveness, the data (Figure 9) shows that most of the respondents $(67.8 \%)$ believe that the government is highly effective, when the public are involved as major stakeholders in the plan-making process. However, $13 . \%$ of the respondents indicate that, in their view, a public-driven plan-making process will have little, or no, impact on the level of government effectiveness. The correlative analysis shows a positive relationship between participation in the plan-making process and ensuring government effectiveness with a correlation of .325. This indicates a moderately strong and significant relationship between participation and government effectiveness

The survey data in Figure 9 also indicate a level of scepticism about the possibility that participation in the plan-making process can reduce corruption. It was seen that almost $40 \%$ of the respondents felt that high-level participation in the plan-making process does not guarantee that corruption in the society will be 
reduced. However, it was still the case that the majority (61\%) believed that corruption in the urban planning system will be significantly reduced by actively engaging the public in the plan-making process. The correlative relationship between participation in the plan-making process and reducing corruption in the society as indicated in Table 3, shows a moderately strong and significant relationship (.250).

Respondents to the questionnaire were asked whether public engagement is enhanced through effective participation of the public in the plan-making process. The survey data in Figure 9 show a central characteristic of the respondents' responses at 3.93 , with about $70 \%$ of the respondents believing that public engagement in society will be high or very high when the plan-making process is public-driven. This suggests that public engagement has the highest level of outcome among other political and institutional outcomes in the urban planning system when the public are actively involved in the plan-making process. Unsurprisingly, the survey data also show that no respondent suggests that public engagement can be achieved without public participation. Public engagement is the only political and institutional outcome that has a relatively strong and significant relationship with participation with a correlation of .410 as shown in Table 3.

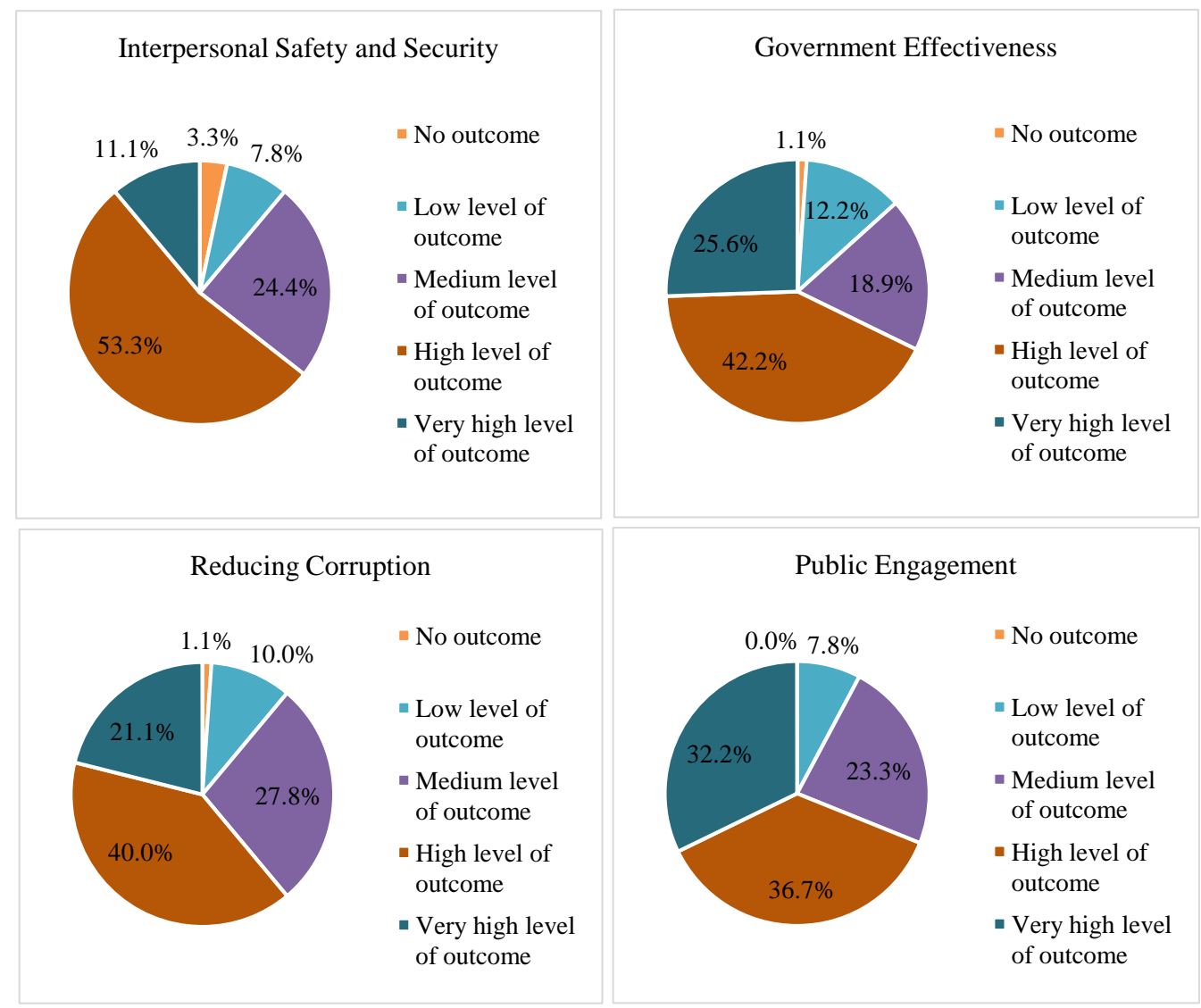

Figure 9. Chart showing the political outcome in the urban planning system, associated with high-level participation in the plan-making process (Source: Author). 


\section{$\underline{\text { Political Indicators }}$}

Table 3. Table showing the correlation between high-level participation in the plan making process and political indicators of social inclusion (Source: Author).

\begin{tabular}{|c|c|c|c|c|}
\hline & Interpersonal_Safety_Security & Government_Effectiveness & Reducing_Corruption & Public_Engagement \\
\hline \multirow{2}{*}{$\mathrm{N}$} & 90 & 90 & 90 & 90 \\
\hline & 0 & 0 & 0 & 0 \\
\hline Mean & 3.61 & 3.79 & 3.70 & 3.93 \\
\hline Std. Deviation & .908 & 1.000 & .953 & .934 \\
\hline Variance & .825 & 1.000 & .909 & .872 \\
\hline Skewness & -.891 & -.595 & -.395 & -.458 \\
\hline Std. Error of Skewness & .254 & .254 & .254 & .254 \\
\hline
\end{tabular}

Importance_of_Participation_Plan_Making_Process

\begin{tabular}{lcc}
\hline & Pearson Correlation & $.368^{* *}$ \\
Interpersonal_Safety_Security & Sig. (2-tailed) & .000 \\
& $\mathrm{~N}$ & 90 \\
\hline Government_Effectiveness & Pearson Correlation & $.325^{* *}$ \\
& Sig. (2-tailed) & .002 \\
\hline Reducing_Corruption & $\mathrm{N}$ & 90 \\
\hline Public_Engagement & Pearson Correlation & $.250^{*}$ \\
& Sig. (2-tailed) & .018 \\
& $\mathrm{~N}$ & 90 \\
\hline
\end{tabular}

${ }^{*}$. Correlation is significant at the .01 level (2-tailed). ${ }^{*}$. Correlation is significant at the .05 level (2-tailed).

Relationship between participation and the economic aspects of social inclusion

The following social inclusion outcomes were grouped under the economic aspects of social inclusion. These were used to evaluate the possible economic outcomes, associated with high-level participation in the plan-making process:

- Employment and empowerment

- Financial system inclusion and investment

- Reducing poverty and inequality

Respondents were asked what level of economic outcomes can be achieved through effective participation in the plan-making process. The data indicates that the majority of the respondents believe that all the economic outcomes of 
social inclusion will be greatly enhanced when the public are involved in the plan making process. As shown in Figure 10, over $63 \%$ of the respondents see high-level participation in the plan-making process as significantly enhancing employment and empowerment in the society. Less than $10 \%$ of the respondents believe that high-level participation in the plan-making process will have little or no impact on employment and empowerment. The data in Table 4 shows a correlation of .368 between participation in the plan-making process and enhancing employment and empowerment in the society. This indicates that their relationship is positive, moderately strong and significant.

The data in Figure 10 also shows that public participation is directly related to financial system inclusion in the labour market. The majority of respondents (63.4\%) suggest that with high-level participation in the plan-making process, achieving financial system inclusion and investment in society will be high or very high. Only $12 \%$ of the respondents see it as having little or no impact on financial system inclusion and investment. The correlative analysis in Table 4 indicates a positive relationship between participation in the plan-making process and achieving financial system inclusion and investment in society. With a correlation of .403, it suggests that the relationship is relatively strong and significant.

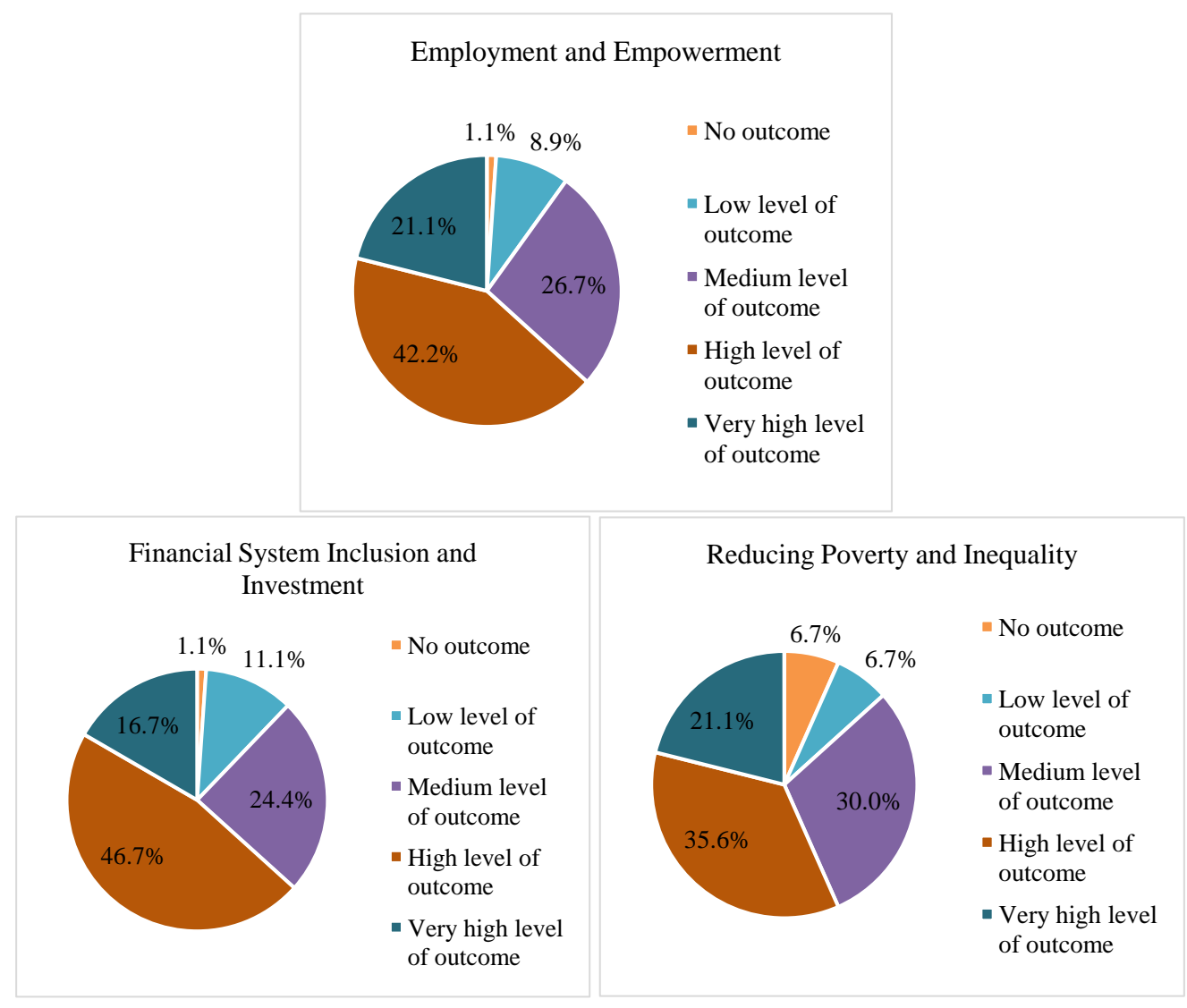

Figure 10. Chart showing the economic outcome in the urban planning system, associated with high-level participation in the plan-making process (Source: Author). 
With regard to reducing poverty and inequality, the survey data show that $43.4 \%$ of the respondents believe that high-level participation in the plan-making process will have moderate or no impact on reducing poverty and inequality in the society. This is the highest level of negative response to any of the survey questions regarding public participation in the plan-making process. However, the majority of respondents $(56.6 \%)$ still believe that when the public participate in the plan-making process, poverty and inequality in the society will be greatly reduced (Figure 10). From the correlative analysis it can be seen that the relationship between participation in the plan-making process and reducing poverty and inequality in society is relatively strong and significant (.404).

Economic Indicators

Table 4. Table showing the correlation between high-level participation in the plan-making process and economic indicators of social inclusion (Source: Author).

\begin{tabular}{ccccc}
\hline & & Employment_Empowerment & Financial_system_inclusion_Investment & Reducing_Poverty_Inequality \\
\hline \multirow{2}{*}{$\mathrm{N} \quad$ Valid } & 90 & 90 & 90 \\
& Missing & 0 & 0 & 0 \\
\hline Mean & 3.73 & 3.67 & .924 & 1.101 \\
Std. Deviation & .934 & .854 & 1.213 \\
Variance & .872 & -.505 & -.641 \\
Skewness & -.455 & .254 & .254 & .254
\end{tabular}

\begin{tabular}{|c|c|c|}
\hline & & Importance_of_Participation_Plan_Making_Process \\
\hline & Pearson Correlation & $.368^{* *}$ \\
\hline \multirow[t]{2}{*}{ Employment_Empowerment } & Sig. (2-tailed) & .000 \\
\hline & $\mathrm{N}$ & 90 \\
\hline \multirow[t]{3}{*}{ Financial_system_inclusion_Investment } & Sig. (2-tailed) & .000 \\
\hline & $\mathrm{N}$ & 90 \\
\hline & Pearson Correlation & $.404^{* *}$ \\
\hline Reducing_Poverty_Inequality & Sig. (2-tailed) & .000 \\
\hline
\end{tabular}

\footnotetext{
${ }^{* *}$. Correlation is significant at the .01 level (2-tailed). ${ }^{*}$. Correlation is significant at the .05 level (2-tailed).
}

Comparative Data Analysis on the Relationship between Participation and the Various Aspects of Social Inclusion.

It can be seen from Figure 11 and Figure 12 that all of the socio-cultural aspects of social inclusion have a strong and significant relationship with participation. This suggests that participation in the plan-making process helps to break cultural barriers and promotes anti-discrimination and intergroup cohesion in society. The analysis also shows that participation in the plan-making 


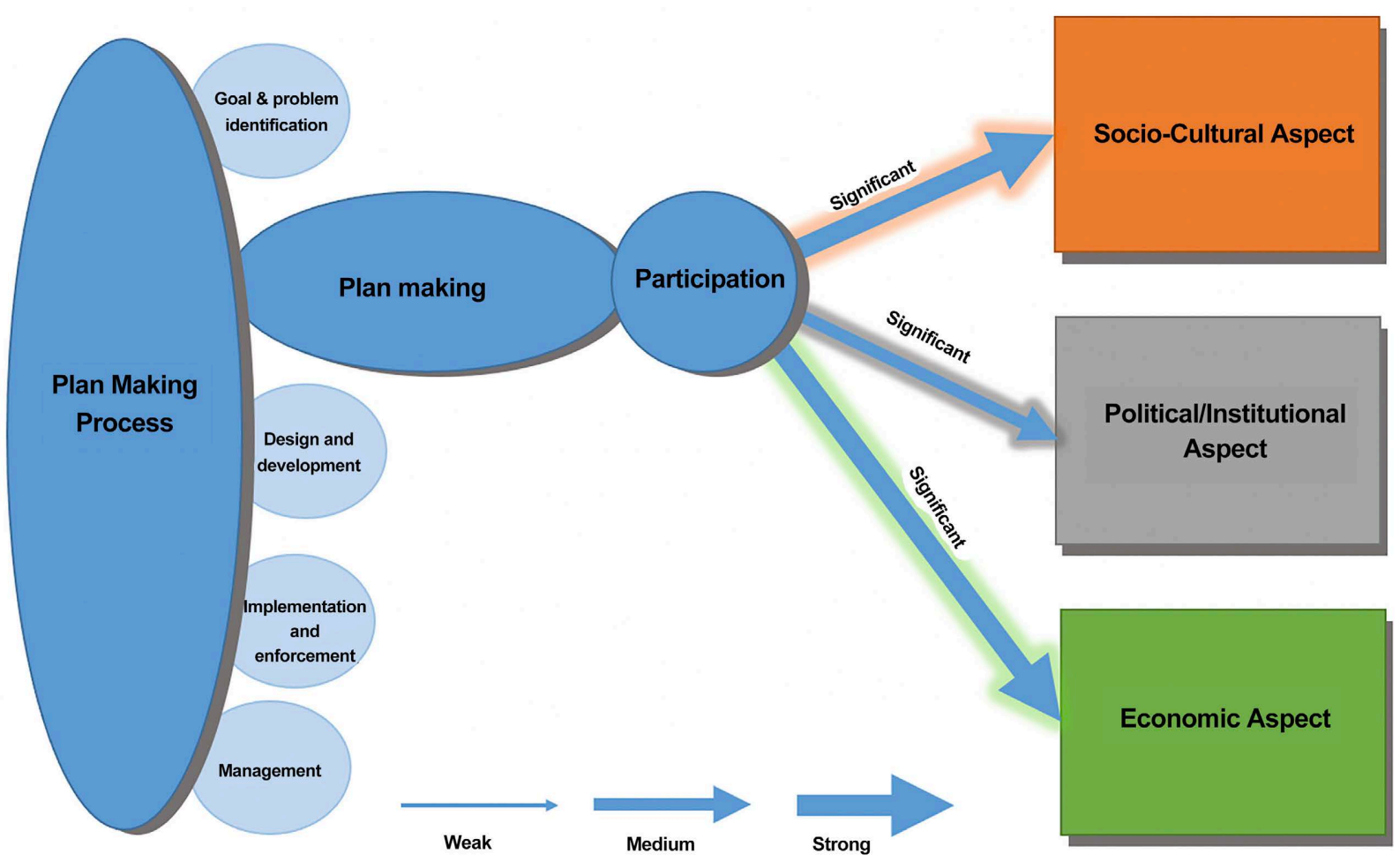

Figure 11. Diagram showing the relationship between participation in the plan-making process and social inclusion outcomes (Source: Author).

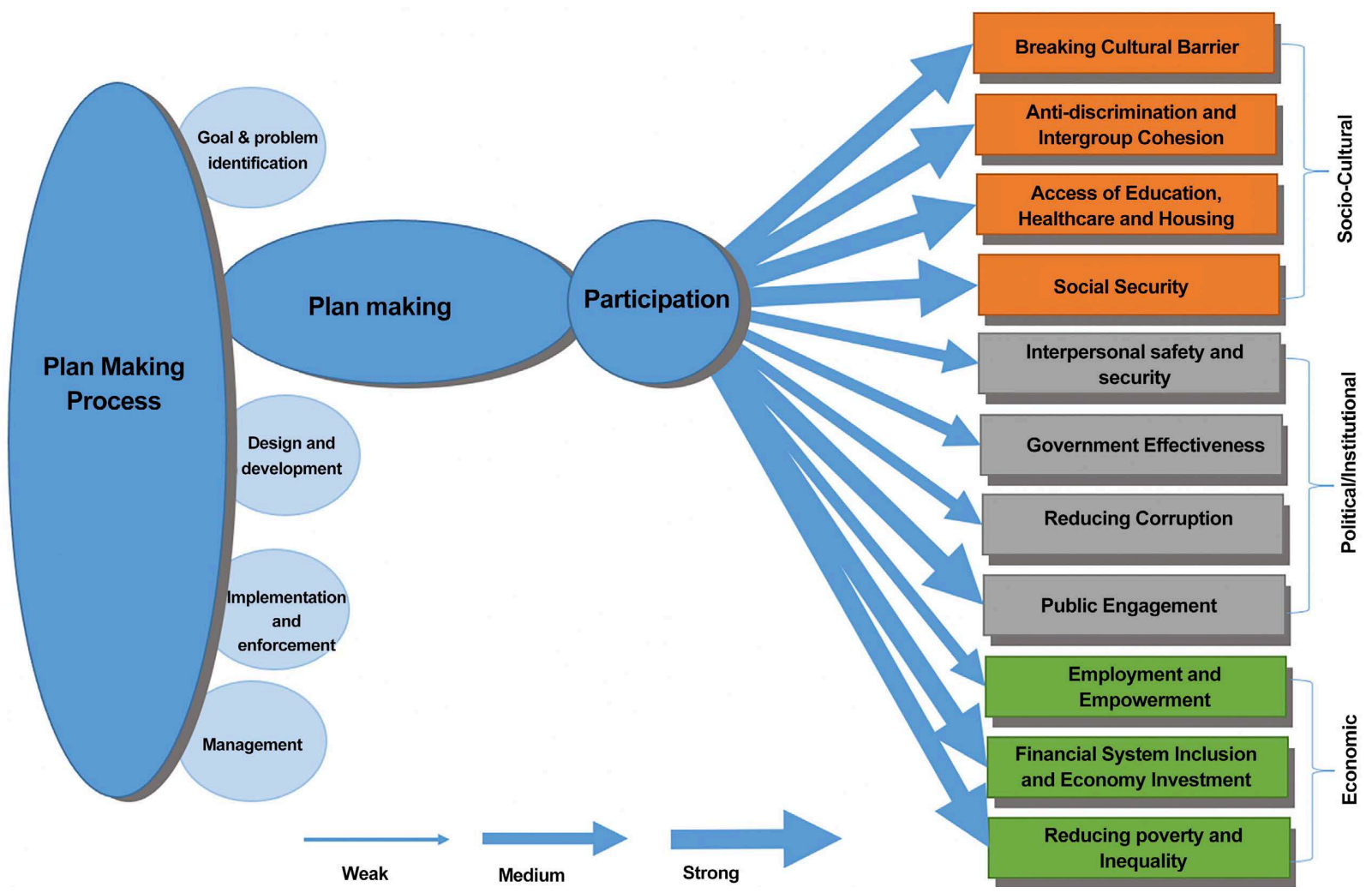

Figure 12. Diagram showing the relationship between participation in the plan-making process and the different aspects of social inclusion (Source: Author). 
process is a tool that can be used to ensure that everyone in the society has access to education, healthcare, housing and social security.

However, the quantitative analysis indicates that the strength of relationship between participation and the political and institutional aspects of social inclusion varied across different indicators. Most of the indicators showed a moderately strong and significant relationship with public engagement as the only political outcome of social inclusion that showed a relatively strong and significant relationship with participation.

It was seen from the quantitative analysis that the relationship between the economic aspects of social inclusion and participation also varied across the different economic indicators. "Financial system inclusion and economy investment", and "reducing poverty and inequality in the society" have a relatively strong and significant relationship with participation. However, "employment and empowerment" as an economic outcome of social inclusion only has a moderately strong and significant relationship with it.

\section{Discussion}

\subsection{Social Inclusion as an Outcome of Participation in the Plan-Making Process}

The literature established that cities in developing countries, which are normally characterised by individualisation and system segregation, are becoming more fragile due to economic, socio-cultural and political differences (UNRISD, 2015; UN-Habitat, 2013a). This has resulted in the demand for more socially inclusive urban planning systems that ensure that social inclusion outcomes are achieved in the society. The research illustrates that, in order for these social inclusion outcomes to be achieved, the plan-making process should be as inclusive as possible, taking account of origin, class and ethnicity. This was highlighted by $85.5 \%$ of the respondents from the research study who believe that effective participation in the plan-making process helps improve social inclusion outcomes. The research indicates that participation is not only an important tool in achieving social inclusion, but also a social inclusion outcome in itself. The two variables are highly dependent on each other, suggesting that the relationship between participation and social inclusion is symbiotic. The more you engage with the public in the plan-making process, the better the social inclusion outcomes will be. And the less you engage with the public, the poorer the social inclusion outcomes will be. Therefore, a high level of public participation that is fully representative is necessary in order to get a good social inclusion outcome.

The research raises questions on the role and approach of political leadership to participation in achieving social inclusion outcomes. It was seen from the research that many plans with high level participation in the plan-making process, especially in cities in developing countries, are delayed or stalled due to poor leadership, or lack of political will to implement the plans. Also, it was observed that some social inclusion projects and outcomes that have benefited society in 
the study area were achieved without the engagement of the public. So, it is the case that social inclusion can be achieved without the input of the public, but, there is general agreement from both the literature and the research that the more the public are involved, the greater the likelihood of a good social inclusion outcome.

\subsection{The Relationship between Participation and the Different Aspects of Social Inclusion}

The key objective of this research is to consider how social inclusion can be achieved through participation in the plan making process. This section presents a discussion and analysis of the research: In particular, it considers the findings in the case study area Abuja, in relation to existing theories and best practices in achieving social inclusion through participation in the plan-making process. In doing so, it will also elaborate the relationship between participation and the various indicators of different aspects of social inclusion.

The relationship between participation and the socio-cultural aspects of social inclusion

The research shows that developing countries tend to be very diverse with different socio-cultural and religious groups making up the society. Challenges pertaining to cultural differences and intergroup segregation often given rise to social exclusion. However, the survey data shows that the strength of relationship varies according to social indicator. The study shows that all of the socio-cultural aspects of social inclusion have a strong and significant relationship with participation. The research highlights that:

Public participation in the plan-making process helps to break down cultural barriers

Different countries have different socio-cultural structures, some more diverse than others which may give rise to social exclusion (Elias \& Scotson, 1965). The literature highlights that cultural and traditional differences have been a major challenge and barrier in most developing cities with different ethnic and cultural groups (Silver, 2015; Otiti, 2015). However, scholars like Cilliers et al. (2011) note that participation in the plan-making process will, not only help promote social and cultural inclusiveness, but also help to break cultural barriers that segregate people in the society.

The research findings support this by indicating a strong and significant relationship between participation and the breaking of cultural barrier in the society. It was ascertained from the response of the majority of survey respondents that effective participation in the plan-making process leads to a break of cultural barriers in the society. The findings show that traditional rulers and representatives have an important role to play in ensuring cultural integration. It was seen that when traditional rulers and representatives are included in the plan-making process, they help to ensure that the cultural values and belief systems that hinder effective plan-making are broken. This is because as the custodians of the different groups, they are entrusted with the responsibility to maintain their 
culture and way of life. It is important that these different groups are fully involved in the decision-making process, because their involvement helps address the challenges relating to cultural barriers and ensures that their community's way of life is considered.

Public participation in the plan-making process enhance anti-discrimination and inter-group co-operation

Anti-discrimination and inter-group co-operation is strengthened through participation in the plan-making process (Green \& Janmaat, 2011; UN, 2016; Imatunga, 2006). The UN-Habitat Report on Urbanization and Development (2016) highlights that empowering different socio-cultural groups in the society, through participation in the plan-making process, will help create a sense of inclusion. It also helps eliminate particular forms of exclusion and discrimination by ensuring the reduction of inequalities between these groups. The literature indicates that effective participation in the plan-making process stimulates information exchange between different groups in the society (Glass, 1979; Cavrić, 2011). This information interchange can further enhance the mutual understanding and relationship between the different groups and promote social capital amongst them (GAC, 2011).

The research findings show that there is a wide gap and differences of socio-economic class in the study area. High-income groups are usually located at the city centre, while low-income groups are on the fringes of the city. Some respondents consider the existing urban planning practice in the study area as discriminatory and non-inclusive. It marginalises and disempowers communities and segregates them according to class. The majority of the questionnaire respondents supports the view that anti-discrimination and intergroup cohesiveness can be achieved through participation in the plan-making process. The response indicates a relatively strong and significant relationship between participation and anti-discrimination and intergroup cohesiveness in the society. The findings from the qualitative data indicate that the participation of indigenous or different socio-cultural groups in the plan-making process, can lead to a more socially inclusive urban planning practice. It helps to build and strengthen relationships between the different socio-economic and cultural groups in the society. It also ensures that the disadvantaged in the society are not segregated or left behind socio-economically.

The research shows that participation of different socio-cultural groups in the plan-making can be the basis for a more socially inclusive urban planning system that promotes anti-discrimination and communal living. The participatory process stimulates information exchange between the different socio-cultural groups, thereby creating a sense of inclusion and enhancing mutual understanding and social capital. Therefore, in order to achieve an inclusive plan, existing planning traditions and practices should be considered in the plan-making process so as to include all socio-cultural and religious groups.

Public participation in the plan-making process enhances the provision of education, healthcare and housing 
The literature shows that participation in the plan-making process positively affects the provision of social amenities in the society (UN-Habitat, 2013b). Most developing countries lack basic social amenities and infrastructure due to the lack of socio-economic investment and participation in their urban planning systems (UN-Habitat, 2013a). The literature also shows that lifelong learning skills and improved public health is directly associated with public participation (Porter et al., 2017). The literature shows that most cities in developing countries lack necessary social infrastructure and amenities, especially in deprived areas. Nevertheless, the research appears to support the view that social amenities such as education, healthcare and housing can be enhanced through effective participation of the people in such areas. It was seen that public participation facilitates public sector partnerships with private investors and the public in the provision of social amenities. This was also supported by the survey data which show a relatively strong and significant relationship between participation and the provision of social amenities in the society.

Public participation in the plan-making process ensures social security

The literature indicates that social security and building social trust is achieved when the marginalised in the community actively participate in activities and projects that concern them (UNRISD, 2015). The UNRISD highlights that participation helps to empower the marginalised in the society, build community, and protect the socially excluded. It is also seen that participation helps to establish social inclusive practices and plans that ensure the basic rights and security of the public (UN-Habitat, 2007). Most of the respondents in this research agree that participation promotes social security in the society. The findings indicate a very strong and significant relationship between participation and social security. This was seen in the study area where social inclusion policies promotes government commitment to social security by investing in social programmes for the poorest and most vulnerable members of society through active public participation. These programmes and policies have helped to reduce regional and local inequalities and marginalisation in the society. The research shows that when the public are well represented in the plan-making process, it will ensure that their concerns in this regard are heard, and that the proposed programmes benefit those in society who need them most.

The relationship between participation and the political aspects of social inclusion

It can be seen from the literature that safety and security in the society; government effectiveness; corruption reduction and public engagement can be enhanced through effective participation in the plan-making process (Kaufman et al., 2006; Kurtz \& Shrank, 2007; Silver, 2015). The quantitative analysis indicates that the strength of relationship between participation and the political and institutional aspects of social inclusion varied across different indicators. Most of the indicators showed a moderately strong and significant relationship with public engagement as the only political outcome of social inclusion that showed 
a relatively strong and significant relationship with participation. The research shows that:

Public participation in the plan-making process promotes interpersonal safety and security

The literature shows that participation in the plan-making process promotes peace, stability, and the rule of law (Kaufman et al., 2006; Kurtz \& Shrank, 2007; Silver, 2015). Participation ensures that the rule of law is maintained in the society by making sure that plans and policies protect the human rights of marginalised groups and provide safety in deprived neighbourhoods (ADB, 2014). Togeby (1999) and Silver (2015) note that public exclusion from the political process leaves the urban poor vulnerable and lacking protection from the system. This indicates that interpersonal safety and security in the society are highly dependent on the ability of the public to participate in making collective decisions about matters that affect their own security (Silver, 2015). The quantitative analysis from the research indicates a significant and moderately strong level of relationship between interpersonal safety and security in the society and public participation in the plan-making process. The majority of the respondents, in both survey and interview, indicate that when the public are part of the plan-making process and their views are taken into consideration, it will reduce the civil unrest and social vices in the society. It was also observed from the research that involving them in the plan-making process gives them a level of control over their environment and encourages them to take responsibility for their security, thereby decreasing thereby decreasing their risk of exposure to violence and crime.

Public participation in the plan-making process improves government effectiveness

The literature highlights that government effectiveness is improved when the public are involved in the plan-making process (Sotomayor-Morales et al., 2017; Kurtz \& Shrank, 2007). Sotomayor-Morales et al. (2017) argue that encouraging the public to participate as political actors in the plan-making process improves government capability to solve urban problems, while Kurtz and Shrank (2007) observe that public participation improves governance. Most urban planning systems in developing countries practice a top-down approach to planning which excludes the public in the plan-making process. This has resulted in a lack development policy implementation and ineffective plan-making in those societies (Watson, 2009; Kamete, 2013). The evidence from the case study area supports this theory. It indicates that that the government has not been effective in the implementation of most plans over the years. This is because the public was not involved in the masterplan preparation and design. The quantitative data shows a significant relationship between participation and government effectiveness, but surprisingly indicates a moderately-strong level of relationship. These variations may be due to the lack of trust in formal government institutions or to the lack of inclusive governance policies and processes. Notwith- 
standing this, the findings show that the majority of the research participants feel that the government will be more effective when the public are involved in the plan-making process. This demonstrates that public participation assists governments to make informed decisions that will impact the community positively.

\section{Public participation in the plan-making process discourages corrupt practices}

The literature shows that lack of public participation in the plan-making process can promote corruption and undermine urban governance, whereas the involvement of the public helps to create accountability and trust (ICPS, 2002). Godfrank and Schrank (2009) argue that public participation is essential in every urban planning system because it aims to deepen democracy, increase transparency, and promote greater efficiency. This was highlighted by the International Centre for Policy Studies (2002) which notes that urban planning institutions and government officials can be made more accountable for their decisions if the public are involved in the plan-making process. It suggests that public participation increases transparency in the decision-making process, thereby reducing the rate of corruption.

In the research findings, it was observed by the interview respondents that most plans in the study area were not implemented or failed to achieve their objective, due to the corrupt practices in the plan-making process. The quantitative findings indicate a significant and moderately strong relationship between participation and the reduction of corruption. This may be due to the current top-down institutional governance practice in the case study area which has made it difficult for the public to hold those in authority accountable. However, significantly the majority of the respondents were of the view that corruption practices in the urban planning system can be drastically reduced with public participate in the plan-making process.

The research established that corruption is one of the major challenges to good governance and urban planning, especially in cities in developing countries due to the lack of public participation in the urban planning system. The research shows that in order to improve transparency and reduce corruption practices in the system, the public should be actively involved in urban governance and plan-making from plan initiation to plan implementation.

\section{Public participation in the plan-making process promotes public en- gagement}

The literature demonstrates that when people participate in the plan-making process, they are likely to engage positively and to get involved in future planning processes (Kelly, 2010; Hopkins, 2001). This was noted in literature, through participation and equality of opportunity of the public in the plan-making process, the public will have access to, and be willing to contribute to, the decision making. This will not only help to enhance real citizen participation, but also serve as an incentive to participate in governance and planning. 
Not surprisingly, the findings show a relatively strong and significant relationship between public engagement and the public participating in the plan-making process. Most of the respondents agree that effective public participation in the planning process promotes public engagement. The respondents note that the continuous involvement of the public helps strengthen the stakeholders' motivation in embarking and participating in various and future plan-making processes. The research indicates that when the public are involved and well represented in the plan-making process, it can serve as an incentive for people to participate further. This is because when people are invited to participate, they feel accepted and more engaged in the plan-making process. The research demonstrates that participation is self-amplifying, that is the public are willing to get involved in future plan-making processes, because they feel their opinions and contributions are valued.

The relationship between participation and the economic aspects of social inclusion

The research indicates that participation of the public in the plan-making process can greatly enhance economic opportunities and reduce poverty in the society. The literature shows that most city dwellers in developing countries still live in poverty, due primarily to lack of access to economic opportunities. It was seen from the quantitative analysis that the level of relationship between the economic aspects of social inclusion and participation also varied across the different economic indicators. However, it shows a significant relationship between participation and the different economic indicators. The research highlights that these economic opportunities can be enhanced in the following ways through participation:

Public participation in the plan-making process promotes empowerment and employment

Participation in the plan-making process can be beneficial in the provision of employment, and empowerment (Cace \& Stanescu, 2013; Venebles, 2015). It can be seen from the literature that public involvement in the plan-making process, empowers them and ensures that their needs are met through the provision of economic opportunities. Dugarova and Lavers (2014) suggest that effective public participation is explicitly intertwined with the employment and economic outputs.

This can be seen from the research that through public participation it helps to invest in the public by increasing social inclusion, creating jobs and improving the human capital base of the economy. The findings also show that through participation government can reduce unemployment and under-employment, particularly among the youth and the marginalised in the society. Surprisingly, the quantitative findings show that there is a significant, but only moderately strong relationship between participation in the plan-making process and employment and empowerment in the society. This may be due to the wealth gap seen in most places, or the lack of economic growth as a result of recession and 
inflation in the study area. Nevertheless, both the quantitative and qualitative data show that the majority of the respondents believe that, with effective public participation in the plan-making process, there will be significant levels of employment and empowerment in the society.

Public participation in the plan-making process promotes financial system inclusion and investment

The theory indicates that in order to promote social inclusion, economic and financial system inclusion programs for the marginalised in the society need to be created (Zamfur \& Dan, 2007). Zamfur and Dan (2007) argue that it is essential that the public are involved in the plan-making process in the development of measures geared towards employment and financial independence. These plans should focus on developing equal opportunities and the elimination of discrimination of economically deprived groups. This will help empower the marginalised in the society through employment and access to modernising labour markets, skill acquisition and training and social protection systems.

The research findings show a significant and relatively strong relationship between financial system inclusion and participation. The majority of the respondents highlight that financial system inclusion and investment can be achieved in the society through high-level participation in the plan-making process. The research shows that when appropriate financial mechanisms are developed through public private partnership programs, the public has the opportunity to benefit financially. This is because it is public-led and the public see themselves as major stakeholders.

Public participation in the plan-making process reduces poverty and inequality

The literature shows that in the most developing cities, spatial segregation by income, class, and group membership affect the chances of disadvantaged groups and individuals in the society to move up the social ladder (Sharkey \& Faber, 2014; Elliott, 2018; Neves et al., 2016). The Department of Economic and Social Affairs, of the United Nations (UNRISD, 2015) pointed out that in order for policies for social inclusion to be developed and implemented, poverty and social exclusion have to be understood and tackled in a balanced and sustainable way. The National Economic and Social Forum (NESF, 2007) suggests that involving the society in the plan-making process will help address the challenges of poverty and social exclusion in the society.

The research findings show a relatively strong and significant relationship between participation and the reduction of poverty and inequality in the society. The majority of the respondents were of the view that public participation in the plan-making process will notably reduce the level of poverty and inequality in the society. Participation of the public in the plan-making process ensures the provision of economic opportunities, thereby reducing poverty and inequality in the society. The research demonstrates that in order to promote social inclusion in the society, poverty, inequality and social exclusion have to be combated and 
this can be done through effective public participation and representation in the plan-making process. It shows that when government institutions empower the marginalised in the society through decision making in the plan-making process, it creates a system that enhances equality of opportunity and eliminates discrimination of different socio-economic groups in the society.

\section{Conclusion}

Both theory and practice show that since the beginning of the 21st century, the promotion of social inclusion and the encouragement of participation have become two of the biggest social policy concerns in urban planning of cities around the world. However, most cities that are mostly characterised by socio-cultural and economic disparities, have been slower to incorporate these policies into their planning. The results of this research impact practice in the following ways:

- The research will inform planners and leaders of urban planning institutions in multi-ethnic and multi-cultural communities on the benefits of involving a variety of stakeholders, including different socio-cultural and economic groups, in the plan-making process.

- This research will inform the development of best practice in plan-making approaches in multi-ethnic and cultural cities in achieving social inclusion outcomes.

- This research exemplifies the benefits of a bottom-up approach to plan-making, as opposed to the top down approach that is currently practiced in most cities.

- This research will assist urban planning authorities in understanding urban planning issues and in how an integrated plan-making approach involving different stakeholders can be used to resolve challenges. In particular, it will inform practice on how participation can help solve social, economic and institutional urban planning issues, especially in multi-cultural and multi-ethnic cities which continue to use colonised urban planning systems.

- This research can assist urban planning authorities and the different stakeholders involved in the urban planning system in understanding their role in the plan-making process and how their contribution can influence the society positively.

- The application of the findings of this research can be used, not only at the plan-making stage of urban planning system, but also at other stages in the plan-making process, such as the problem identification stage, development and design stage, implementation stage and management stage.

- The results of this research will help foster collaboration of stakeholders in the urban planning system by informing the different socio-economic and cultural groups in the society of the benefits of collaborating in the plan-making process. It can help create awareness and provide information on how institutional and public collaboration can lead to social, institutional and economic change. 
In conclusion, the research indicates that there is a strong and significant relationship between participation and the socio-cultural aspects of social inclusion. It shows that participation in the plan-making process can significantly improve access to social security, promote intergroup cohesiveness, break down cultural barriers and reduce discrimination, especially in cities in developing countries where it is prevalent. It also indicates that access to basic social amenities, such as housing, healthcare and education, can be improved through effective public involvement in the plan-making process. The research also indicates that the political and institutional aspects of social inclusion such as interpersonal safety, government effectiveness, corruption reduction and public engagement have a strong and significant relationship with public participation. It shows that in order to promote good governance and achieve an inclusive society with effective institutions, a participatory process that involves everyone in the society should be fostered. Finally, the research shows that there is a strong and significant relationship between participation and the economic aspect of social inclusion. It shows that employment, empowerment, and financial system inclusion can be enhanced in the society through participation of the public in the plan-making process. It also shows that participation can be used as a tool to reduce poverty and inequality.

The practical implication of this study is that it shows and outlines how social inclusion outcomes can be achieved in the society through inclusive, comprehensive, robust, and evidence-based plan-making. This will not only help improve economic and institutional outcomes in the urban planning system, but will also help to reduce social exclusion, strengthen and build intergroup cohesion, and to provide opportunities to the marginalised in society.

\section{Conflicts of Interest}

The author declares no conflicts of interest regarding the publication of this paper.

\section{References}

ADB (2014). Guidance Note: Poverty and Social Dimensions in Urban Projects. Asian Development Bank.

Andrew, M. (2015). Mapping Social Cohesion. The Scanlon Foundation Surveys 2015. Monash University.

Brenman, M., \& Sanchez, T. W. (2012). Planning as If People Matter: Governing for Social Equity. Island Press.

Cace, S., \& Stanescu, S. M. (2013). Role of the Social Economy to Increase Social Inclusion. Procedia Social and Behavioural Sciences, 92, 117-121. https://doi.org/10.1016/j.sbspro.2013.08.646

Cambir, A., \& Vasile, V. (2015). Material Dimension of Life Quality and Social Inclusion. Procedia Economics and Finance, 32, 932-939. https://doi.org/10.1016/S2212-5671(15)01551-8

Cavrić, B. (2011). Evolution of Botswana Planning Education in Light of Local and Inter- 
national Requirements. Spatium, 25, 30-38. https://doi.org/10.2298/SPAT1125030C

Cilliers, E. J., Diemont, E., Stobbelaar, D. J., \& Timmermans, W. (2011). Sustainable Green Urban Planning: The Workbench Spatial Quality Method. Journal of Place Management and Development, 4, 214-224. https://doi.org/10.1108/17538331111153197

Cohen, J. (1988). Statistical Power Analysis for the Behavioural Sciences. Academic Press.

Siegle, D. (2015). Critical Values of the Pearson Product-Moment Correlation Coefficient. Neag School of Education, University of Connecticut.

Dugarova, E., \& Lavers, T. (2014). Social Inclusion and the Post-2015 Sustainable Development Agenda. Paper prepared for the UNITAR's Briefing for UN Delegates on Post-2015 Development Agenda: Social Inclusion, UNRISD.

Elias, N., \& Scotson, J. (1965). The Established and the Outsiders. Cass \& Company.

Elliott, L. (2018). Inequality Gap Widens as 42 People Hold Same Wealth as 3.7bn Poorest. The Guardian.

Fainstein, S. S. (2010). The Just City. Cornell University Press. https://doi.org/10.7591/9780801460487

Fernandez-Borrero, M. A., \& Vazquez-Aguado, O. (2014). La sensibilidad intercultural en población autóctona. Análisis tipológico de la realidad andaluza. Revista Internacional de Estudios Migratorios, 42, 145-176.

Fiskaa H. (2007). Past and Future for Public Participation in Norwegian Physical Planning. European Planning Studies, 13, 157-174. https://doi.org/10.1080/0965431042000312451

Forester, J. (1999). The Deliberative Practitioner: Encouraging Participatory Planning Processes. The MIT Press.

Fung, A., \& Wright, E. O. (2001). Deepening Democracy: Innovations in Empowered Participatory Governance. Politics \& Society, 29, 5-41.

https://doi.org/10.1177/0032329201029001002

GAC (2011). Integrated Urban Development Planning and Urban Development Management-Strategies and Instruments for Sustainable Urban Development. German Association of Cities.

Glass, J. (1979). Citizen Participation in Planning: The Relationship between Objectives and Techniques. Journal of the American Planning Association, 45, 180-189. https://doi.org/10.1080/01944367908976956

Godfrank, B., \& Schrank, A. (2009). Municipal Neoliberalism and Municipal Socialism: Urban Political Economy in Latin America. International Journal of Urban and Regional Research, 33, 443-462. https://doi.org/10.1111/j.1468-2427.2009.00834.x

Green, A., \& Janmaat, J. (2011). Regimes of Social Cohesion: Societies and the Crisis of Globalization. Palgrave Macmillan. https://doi.org/10.1057/9780230308633

Hall, P., \& Tewdwr-Jones, M. (2011). Urban and Regional Planning (5th ed.). Routledge. https://doi.org/10.4324/9780203861424

Hopkins, L. D. (2001). Urban Development; The Logic of Making Plans. Island Press.

ICPS (2002). Citizen Participation Handbook. People's Voice Project. Kyiv Ukraine: International Centre for Policy Studies.

Imatunga, H. (2006). The Concept of Indigenous Planning as a Framework for Social Inclusion. Centre for Maori \& Indigenous Planning \& Development.

Jiriko, K. (2008). Urban Master Planning Paradigm in Nigeria: What Future? MBA Prints+Graphics.

Jones, A. (2008). The Governance of Sustainable Development: Taking Stock and Looking 
Forwards. Environment and Planning C: Politics and Space, 26, 17-33.

Jones, H., Cummings, C., \& Nixon, H. (2014). Services in the City: Governance and Political Economy in Urban Service Deliver. ODI.

Kalenzig, W. (2011). Delivering Effective Urban Management. In UNDESA, Shanghai Manual: Guide for Sustainable Urban Development in the 21st Century. UN.

Kamete, A. Y. (2013). On Handling Urban Informality in Southern Africa. Geografiska Annaler: Series B, Human Geography, 95, 17-31. https://doi.org/10.1111/geob.12007

Kaufman, D., Kraay, A., \& Mastruzzi, M. (2006). Governance Matters V: Aggregate and Individual Governance Indicators for 1996-2005. World Bank. https://doi.org/10.1596/1813-9450-4012

Kelly, E. K. (2010). Community Planning: An Introduction to the Comprehensive Plan (2nd ed.). Island Press.

Kingston, R. (1998). Accessing GIS over the Web: An Aid to Public Participation in Environmental Decision Making. Proceedings of the Workshop of the International Association for Public Participation, SPICE '98, Tempe Arizona, 3-7 October 1998. http://http://www.iap2.com/a kingston.htm

Kirby, P., Lanyon, C., Cronin, K., \& Sinclair, R. (2003). Building a Culture of Participation. Involving Children and Young People in Policy, Service Planning, Delivery and Evaluation. Department for Education and Skills.

Kurtz, M., \& Shrank, A. (2007). Growth and Governance: Models, Measures, and Mechanisms. Journal of Politics, 69, 538-554. https://doi.org/10.1111/j.1468-2508.2007.00549.x

Mabogunje, A. L. (2001). Abuja: The Dream, Conception and the Product' in Ministry of Federal Capital Territory, the Review of Abuja Master Plan.

Mabogunje, A. L. (2002). Knowledge, Planning and Effective Urban Governance. Paper presented at the N.I.T.P Annual Conference, University of Ilorin, Nigeria, 30 October-1 November 2002.

Marzuki, A. (2015). Challenges in the Public Participation and the Decision Making Process. Universiti Sains Malaysis, Flinders University.

Mitlin, D., \& Thompson, J. (1995). Participatory Approaches in Urban Areas: Strengthening Civil Society or Reinforcing the Status Quo? Environment and Urbanization, 7, 231-250. https://doi.org/10.1177/095624789500700113

NESF (2007). The Arts, Cultural Inclusion and Social Cohesion. The National Economic and Social Forum.

Neves, P. C., Afonso, O. S., \& Silva, S. T. (2016). A Meta-Analytic Reassessment of the Effects of Inequality on Growth. World Development, 78, 386-400.

https://doi.org/10.1016/j.worlddev.2015.10.038

Otiti, O. (2015). Nigeria’s Identifiable Ethnic Groups. OnlineNigeria. https://onlinenigeria.com/tribes/tribes.php

Oyesiku, O. K. (2004). Town and Country Planning Law and Administration in Nigeria. In T. Agbola (Ed.), Readings in Urban and Regional Planning (pp. 257-269). Macmillan.

Pearson, K. (1895). Contributions to the Mathematical Theory of Evolution, II: Skew Variation in Homogeneous Material. Philosophical Transactions of the Royal Society, 186, 343-414. https://doi.org/10.1098/rsta.1895.0010

Porter, M. E., Stern, S., \& Green, M. (2017). Social Progress Index 2017. Social Progress Imperative. 
Schoukens, P., De Becker, E., \& Smet, J. B. (2015). Fighting Social Exclusion under the Europe 2020 Strategy: Which Legal Nature for Social Inclusion Recommendations? International Comparative Jurisprudence, 1, 11-23. https://doi.org/10.1016/j.icj.2015.10.003

Shah, A., \& Shah, S. (2006). The New Vision of Local Governance and the Evolving Roles of Local Governments. In A. Shah (Ed.), Local Governance in Developing Countries. World Bank. https://doi.org/10.1596/978-0-8213-6565-6

Sharkey, P., \& Faber, J. W. (2014). Where, When, Why, and for Whom Do Residential Contexts Matter? Moving Away from the Dichotomous Understanding of Neighborhood Effects. Department of Sociology, New York University. https://doi.org/10.1146/annurev-soc-071913-043350

Shortell, T. (2001). An Introduction to Data Analysis and Presentation. Brooklyn College: Sociology.

Silver, H. (2015). The Contexts of Social Inclusion. DESA Working Paper No. 144. https://doi.org/10.2139/ssrn.2641272

Slack, E., \& Cote, A. (2014). Comparative Urban Governance (Future of Cities: Working Paper). Foresight, Government Office for Science.

Sotomayor-Morales, E., Grande-Gascon, M. L., \& Ajaaouani, N. (2017). The Social Inclusion of the Immigrant Population in Europe through the Development of New Teaching and Learning Methods in Vocational Training. Procedia Social and Behavioural Sciences, 237, 535-540. https://doi.org/10.1016/j.sbspro.2017.02.103

Stigler, S. M. (1989). Francis Galton's Account of the Invention of Correlation. Statistical Science, 4, 73-79. https://doi.org/10.1214/ss/1177012580

Togeby, L. (1999). Migrants at the Polls: An Analysis of Immigrant and Refugee Participation in Danish Local Elections. Journal of Ethnic and Migration Studies, 25, 665-684. https://doi.org/10.1080/1369183X.1999.9976709

UDP (2013). Guide for Participation in Urban Planning. Urban Development Program, GIZ/AMBERO-ICON Project.

UN (2010). Analysis and Measuring Social Inclusion in a Global Context. Department of Economic and Social Affairs, UN.

UN (2016). Global Sustainable Development Report. Department of Economic and Social Affairs, UN.

UNDESA (2014). World Urbanization Prospects. United Nations, Department of Economic and Social Affairs, Population Division.

UN-Habitat (2007). Inclusive and Sustainable Urban Planning: A Guide for Municipalities. UN-HABITAT.

UN-Habitat (2009). Planning Sustainable Cities: Global Report on Human Settlements 2009. United Nations Human Settlements Programme (UN-Habitat).

UN-Habitat (2013a). Urban Planning for City Leaders. United Nations Human Settlements Programme (UN-Habitat).

UN-Habitat (2013b). Urban Equity in Development-Cities for Life. United Nations Habitat.

UN-Habitat (2016). Urbanization and Development: Emerging Futures (World Cities Report 2016). UN-Habitat.

UNRISD (2015). Social Inclusion, Poverty Eradication and the 2030 Agenda for Sustainable Development. United Nations Research Institute for Social Development.

Venebles, T. (2015). Making Cities Work for Development. (IGC Growth Brief 2). Inter- 
national Growth Center.

Watson, V. (2009). “The Planned City Sweeps the Poor Away...”: Urban Planning and 21st Century Urbanisation. Progress in Planning, 72, 151-193.

https://doi.org/10.1016/j.progress.2009.06.002

WHO (1999). Towards a New Planning Process: A Guide to Reorienting Urban Planning towards Local Agenda 21. In European Sustainable Development and Health Series 3.

Zamfur, E., \& Dan, M. (2007). Social Exclusion. In C. Zamfir, \& S. M. Stanescu (Eds.), Encyclopaedia of Social Development. Polirom Publishing House. (In Romanian) 